\title{
Metafiction and Humour in The Great Escape from City Zoo
}

\author{
Cheryl McMillan
}

$\mathrm{P}$ layfulness and parody have been well recognised as an easy tendency in the picture book form. Referring to this natural tendency, as well as to its openness and flexibility, Lewis (1990, p.143) has seen the picture book as 'fertile ground in which the metafictive can flourish'. One special feature of postmodernist picture books is their widespread use of metafiction to draw young readers' attention to the processes of story and how meaning is made. Within the general purposes of metafiction, to expose text as a fiction and to generate reader movement between internal and external positions constructed by the text, some quite specific textual/ linguistic functions may be realised in picture book discourse. In part, such functions emerge through the dualities inherent in the picture book form which support its propensity to playfulness. Picture book composition, too, is a textual element which contributes significantly to the range of play available and can help to suggest how the text is to be read. In the capacity of the visual code to succinctly narrow the signification of a verbal text (Nodelman 1988), the tension between the codes may also effectively foreground how meaning is culturaliy determined and may be available through a knowledge of intertexts.

The use of humour in specific forms is one element that can reflect on the linguistic and social construction of meaning and call readers into active role play with a text. Humour in picture book discourse generally denotes comic humour and in this context may be defined as degrees of laughter and/or amusement that ensue from an audience's appreciation of visual or verbal jokes or from a relationship between the codes that generates comic tension. Textual humour can arise when authors/ illustrators play with readers' expectations. Because a representation becomes comic when it defies the way in which readers usually think, or when it extends commonly held logic, comic humour can be a useful resource in challenging habits of thought. McCallum (1996, p.398) has pointed to the 'relationship between play-oriented activities, such as verbal puns, jokes and rhymes ... and the acquisition of language and of complex cognitive and social skills' as a means of assisting reading development. Like metafiction, the use of humour foregrounds the gap between signs and theiz referents, because the language of humour implicates a dialogue which can rely on an audience's recognition of a gap or incongruity in the communication for the humour to take effect (Nelson (1990, p.124).'

Picture books can employ the visual code to extend a humorous situation created by the words or to subvert the words by encoding pictorially an unconventional response to them. In some cases, a joke is orchestrated by the picture code (see Anthony Browne's visual puns) with seemingly no reference to the verbal text. Linguistic subtlety that creates humorous effects is, however, often unsuccessfully negotiated with the primary audience of a picture book who are still 'developing awareness that words can be multi-functional' (Stephens 1989, p.33). As Stephens has pointed out, children often come back to multi-layered texts and then may enjoy them on another level. What seems basic in engaging children's interest in layered or subtle texts is that story is tecuperable at least at a primary level, before any other criteria are met.

Cartoons designed to pass political comment lend an example of a complex form of humour which is replicated in some sophisticated picture books. These cartoons tend to rely on an audience's knowledge of intertexts and on that audience's cultural orientation and experience to appreciate the humour of the irony represented. To reduce anbiguity in the message, a cartoonist will sometimes provide verbal cues in the form of labels on depicted objects within an iliustration. Metafictive picture books can work on similar principles, but since the picture book tells a story in more than a single frame, the 'labeis' may be found in story context, parallels, or by narratorial intervention. Metafictive picture books often make 'parodic appropriations of other texts' (McCallum 1996, p.397), using well-known children's texts as intertexts. Janet and Allan Ahlberg's The Jolly Postman (1986) and Jon Scieszka's and Lane Smith's The Stinky Cheese Man (1992) are classic examples. However, intertextuality in children's texts is always problematic (see Stephens 1992a) and in the work of Anthony Browne, David Wiesner and Tohby Riddle it operates very widely, drawing not only on texts that are well-known children's stories, but also on texts and cultural discourses that are only partially, if at all, recuperable for child readers. One

Copyright of Full Text rests with the original copyright owner and, except as permitted under the Copyrigh 1968 , copying this copyright material is prohibited without the permission of the owner or is prohibited without the permission of the owner or its exclusive licensee or agent or by way of a licence from Copyright Agency Limited. For information about such licences contact Copyright Agency 
aspect of this difficulty, with implications for the construction of a dual audience, is that in a picture book, before composite meaning is made, each semiotic code has its own independence. So although these references may reflect the larger significance of the narrative and enact a dialogue with it, they do not crucially drive the primary narrative. Their presence in the text becomes part of the acculturating process.

Hunt's examination of allusiveness in texts has focused on the two skills required to understand a text 'understanding what the language signifies - what it refers to - and understanding the rules of the game - how the text works' (1988, p.218). In picture books metafictive strategies can deliver those cues which 'foster an awareness of how a story works' (Mackey 1990, p. 181). At the same time, by foregrounding language - making selections where meaning (and the joke) depends on readers grappling with the syntagm or with the paradigmatic function of language, and then endorsing the selections with visual and verbal cues - linguistic playfulness can actively teach reading comprehension. The syntagm or horizontal axis of language, which denotes the order and arrangement of words, interrelates with the paradigm or vertical axis, which generates the choices of meaning that arise from a word or word arrangement (see Stephens and Waterhouse 1990 for a fuller definition of these terms). Children's texts which exploit the semiotic instability of language as a source of humour often reveal a clear interest in language acquisition and linguistic competence.

In picture books some of the cues which reinforce both the sense and significance of a narrative are found in compositional factors. Picture book composition, along with techniques made available by the marriage of dual codes at once at varying degrees of independence. interdependence and dependence, can be a tool for ironic and potentially humorous effect. When picture books play on the interrelationships suggested by compositional elements of the form to produce ironic outcomes, the spatio-temporality of the text is implicated. In her study of narrative and discursive techniques in metafictive children's fiction, McCallum investigates ways in which the spatio-temporality of a narrative may be distupted to metafictive effect. One strategy she describes is narrative metalepsis: "Metalepsis refers to the transgression of logical and hierarchical relations between different levels of narration' (McCallum 1996, p.403, acknowledging Genette 1980, pp. 234-235; McHale 1987, 1989, p.119). The spatial composition and the rhythm of a composite or multi-modal text ${ }^{2}$ deternine its logic (Kress and van Leeuwin 1990,1996 ) and these narratival functions are often utilised to create suspense, a surprise effect (often humorous) or to teach linearity, as when signifiers which complete the sense of a page-spread are supplied overleaf. Such devices do not tend to be explicitly self-conscious forms, given that they are conventions in picture book discourse and do not actively steer readers' attention to the processes of fiction. (As Ommundsen 1993, p.27 has argued. a text's latent reflexivity is activated finally by the reader.) However, sometimes the text's spatial composition and shythm may be disrupted in an explicitly metafictive way. By juxtaposing words and/or illustrations in particular compositional arrangements and creating disjunctions in the rhythmic patterns, an author/illustrator may point to the see-sawing control passed between verbal and visual functions and to readers' intertextual knowledge in vesting the text with composite meaning. The effect can be considered metaleptic in that the narrative reins are handed between author, illustrator, character and reader and the shift in control foregrounds the shared role of each in the determination of meaning.

Tohby Riddle's The Great Escape from City Zoo (1997) demonstrates a persistent and varied treatment of metafictional playfulness that works to create humour. The narrative follows a literary tradition which selfconsciously thematises play and it employs many of the metafictive, playful devices Grieve has re-identified, including "puzzle-solving ...: playful, "lying" or unreliable narrators: linguistic play,... and playing with or "reworking genre conventions and established literary codes by means of parody and intertextuality to discover the new possibilities of the literary game" (Grieve 1998. p.6). Riddle's text shares features of the children's carnivalesque text (Stephens 1992a) in that it narrativises the sign/thing relationship in such a way that foregrounds verbal play as fundamental in the construction of meaning. In carnival "where linguistic playfulness is directed towards a problematising of the world's serious, but 
unthinking, acceptance of unconditional meanings, social structures and ideological paradigms' (Stephens 1992a, p.156), reading positions shift to allow for transferred perspectives. In The Great Escape the visual code is used as a weapon of parody to undercut the assumptions forged by the verbal code. The subtiety of some of The Great Escape's textual references implicates a dual audience, but the primary audience is often called into an active engagement with some sophisticated yet childaccessible linguistic play. In its narrativisation of language play The Great Escape follows some of Russell Hoban's work, especially his novel. The Mouse and His Child (1967) and his picture book and modern fairy tale collection, La Corona and the Tin Frog (1974), which self-consciously explore how words and language shape our response to the world. Though linguistic play is selfconscious in texts such as these, it is not tied to comedy, as in The Great Escape.

Partly because it is oriented in a particularly metafictive way, and shows language to be 'an arbitrary system of signs' (Moss 1992, p.65), The Great Escape exhibits many of the features associated with postmodernist fiction. Some postmodernist features are endernically present in picture books, such as the mixing of genres and codes (Stephens 1992b) and a propensity to playfulness, and many postmodernist techniques have been appropriated in picture books to become what Stephens has described as a 'conventional postmodernism in children's literature' (Stephens 1992b, p.53). If conventionally postmodernist. a postmodernist approach fits the purposes of The Great Escape which are tied to the creation of humour. Nelson has pointed to the close link between metafictional techniques and comedy. These techniques lend themselves to comic procedures such as playing 'tricks based on illusion' and making a joke 'out of the tenuousness of the grasp human beings have on reality' (Nelson 1990, pp. 151-152). In The Great Escape devices such as mise en abyme ${ }^{3}$. intertextuality, challenging the authorial role, parodic and ironic forms, indeterminacy and indefinite closure are used as a combination of expressive techniques that, in sum, playfully expose the socio-cultural construction of reality. The text does not merely foreground the ontological distinction between fiction and reality, or art and life, and between words and their referents, but it uses satire to comment on ways of viewing the world. This kind of textual practice points to the capacity of picture books to address the linguistic and social issues which might develop children's language competence and their awareness that texts work on several levels. In this way The Great Escape adopts a theoretical stance common to many postmodernist children's texts, whereby postmodernist concepts and strategies are seen to fit traditional challenges in children's fiction, such as 'sowing the seed for linguistic expansion' (Stephens $1989, p .33$ ) and 'deriving pleasure and making meaning through play' (Moss 1992, p.54).

Within the conventional narrative structure, the discourse enacts a series of jokes that play on literal and metaphorical meanings and real and fantasy encodings. Both the jokes and Riddle's use of metafictive strategies seem designed to 'compel us to break through the complacency of patterned responses' (Moss 1992, p.53, citing WhalenLevitt 1984, p.6). The text's humorously invoked cuitural comment situates the dual audience as observers of postwar society, but to an extent some readers are participants, because in their making sense of particular allusions they help to construct the rather ridiculous (suggests Riddle) (post)modern world. This then tends to remove the child audience from the author's gently parodic cultural comment. The sepia-tinged drawings also help to achieve this effect, by evoking a past not well known to the primary audience, but perhaps within the experience of adult readers for whom the allusions may create some sense of nostalgia. Parodic references to the mythology built on pop culture icons such as the Beatles, King Kong and the Loch Ness monster perpetuate a tradition of story fragments that become incorporated into the cultural discourses that children gradually learn and by which they make sense of the world. As observers, the audience views the author-illustrator's represented world through the bold black frames of the illustrations. This physical framing of the pictures creates distance between the story world and the reading audience. The verbal text stands outside the framed illustrations, almost as captions, and, being less physicaliy embedded than the illustration, it invites linguistic decoding before visual decoding at a deeper textual level. In this way the illustrations bring most of the symbolism to the text and clinch the decoding 
of meaning as a collaborative production between reader and viewer and between words and pictures. An overt statement of this technique is realised in the last two story frames. In the former of the two the verbal text stands alone dramatically and words are the focus. Then in the last black-framed illustration the two foregrounded characters for the first time in the story meet readers with a frontal gaze, the device being used to establish contact between the participants. The characters' laughing smile signifies 'a relation of (strong) social affinity' (Kress and van Leeuwin 1996, p. 123). The medium close shot (using the language of film) of these two characters equates to 'far personal distance' which is 'the distance at which subjects of personal interests and involvements are discussed' (Kress and van Leeuwin 1996, p.130, citing Edward Hall, 1966). So although the text's mild satire sometimes excludes the child audience, children are still drawn into the humorously allusive world of the text, if at different textual levels.

Intertextual reference directly encompasses children's experience as in - "during a daring visit to a truckstop...the turtle fell on his back and couldn 't get up'. This reference to the nature and habits of animals (which children usually know well) works as humour by its relationship to the context, although in this case encoding of the comic situation may also derive from theories of superiority (see Langer 1953). More instructively for the reading process, the joke demands that readers infer the narratival or intratextual link. At a thematic and more symbolic level, the text provides explicit cues so that the child audience can make the intratextual comparison which sees the primary narrative work as an allegory of the metafictional framing. In the story eventually the anteater, the turtie and the elephant are publicly exposed as fakes, because their essential nature prevents them from sustaining the pretence. Thus, the primary narrative is embedded in and replicates the framing of the narrative, whereby the animal characters must step within a frame (an illustration of this accompanies the author's acknowledgements) and temporarily disguise their 'real' nature so that the story fun can take effect. At the end the characters acknowledge the participation of the reading audience as the instrumental link in the designs of fictionality. In critical terms Riddle's text might call to mind Hutcheon's words: 'In its most overt form the self-consciousness of a text often takes the shape of an explicit thematisation - through plot allegory, narrative metaphor, or even narratorial commentary'(Hutcheon 1984, p.23).

Narrative metaphor operates in different ways in The Great Escape. Riddle makes use of mise en abyme to focus readers' attention on the central concerns of the narrative. Clearly, the famous Magritte 'Ceci n'est pas une pipe', which is reproduced in the illustration of the animals 'blending in' at an art gallery, is beyond the implied child reader's ken. Similarly, the reproduction of Edward Hopper's 'Nighthawks' to reflect the difficulty of surviving in a big city is an allusion bound to be missed by the child audience. However, the themes reflected in these references skirt the central theme of play which is also encoded as a mise en abyme, but which seeks the attention and involvement of the child audience. On the only doublespread illustration in the text, an elongated picture shows the elephant, turtle and flamingo occupying one of the wagons of a train which is 'leaving the city further and further behind'. On close inspection, the audience notices that the animals are sharing a game of cards. The direction of the train is represented as a rightleft structuring, an inversion of the general left-right structuring in horizontal composition (Kress and van Leeuwin 1996). This inversion accords with the employment of the temporal marker 'meanwhile' in the illustration's accompanying verbal text. However, the general principles of pictorial salience (see Kress and van Leeuwin 1996, pp. 212-214) are also inverted in this illustration, because the most salient feature, the cardplaying, is represented in miniscule form. Search tasks are highly motivating for young children and require very little verbal competence (Marzolf and Deloache 1997). Searching for visual motifs, often minute or disguised within an illustration, is a common form of play in children's texts (A Walk in the Park (1977), Voices in the Park (1998), The Tip at the End of the Street (1996), Where's Wally series), so the device seems to playfully mirror the text's elemental theme of game-playing and specifically invites the child audience's involvement.

So, too, is narratorial commentary included in The Great Escape. The narrative is 'short circuited' (Lodge 1981, 
p.15) at the story closure by using picture book space in a metafictional way (see Grieve 1993). Here a black page with white typeface arrests the audience's temporary immersion in the story world with the narrator's written claim for the truth status of the narrative. The verbal code on this page makes explicit reference to the intertextuality of fabulation and to the claim of a focused text to represent a truth. However, in the last story illustration the narrative's 'truth' is overturned by the animals. The last laugh then belongs to the characters, who invite the audience, especially the young audience, to share at the expense of the implied author. This is cheekily endorsed on the back flap cover of the hardback edition with its inset illustration of the animal characters and the implied author together at table. Here the author and the characters share the same fictional world, but the anteater makes a playful 'rabbit's ears' gesture behind the depicted author's back. In effect, all story participants share and collaborate in the fictional world, but the laughter that springs from the gentle mockery of the authorial role is 'a song of triumph' (Pagnol 1947. p.41) on children's terms.

Sometimes a joke is dependent on the audience's understanding of an unfamiliar signifier, whose possible meanings are determined at the syntagmatic level, as in . 'he (the anteater) fainted outside a taxidermist'. This vocabulary exercise is reinterpreted in playful thyme as part of the signage above the shop window in the illustration, 'You snuff 'em We stuff 'em'. The contexilinked signifiers 'snuff' and 'stuff' probably represent a further linguistic challenge for a young audience. However, further cues to understanding are supplied pictorially by the plaque-mounted animal heads. The text offers some examples where the language works in conjunction with the pictures, but with obvious multifunctional effects. For example, the anteater's 'holding down a regular job' which enables him to live 'on the outside quite successfully', is interpreted pictorially with the anteater working on a construction site (like the audience?) and perched on scaffolding above the highest skyscrapers. Arms outstretched, he waits to receive some building material about to be delivered by crane. The child audience may find the illustration funny in the manner of slapstick, but is also drawn to infer meaning from the idiomatic expression, "holding down a regular job'. Young children may interpret this expression quite literally, since the illustration could suggest that the girder will have to be held down. Then, within the expression, the dual audience is invited to imagine a range of play for the phrase 'a regular job'. The visual code's illustration of this phrase inverts conventional elaboration (Barthes) of the words by narrowing the signification in an unexpected way. At the same time the illustration encodes a response which humorously extends the expected range of play for the signifier and which creates an awareness of other worlds. Although the effect is ironic, the codes are not really opposed. Nevertheless they do operate in the manner of relay, where the composite text realises a transformation of meaning (see Kress and van Leeuwin's (1996, p.68) application of Barthes' term), because the text positions the reading audience in a speculative role. The device operates metafictively because through the illustration the audience is distanced from the text by being obliged to recognise the authorillustrator's unconventional interpretation of language, and at the same time, the arbitrary nature of the sign. Then, for another intertextual reading, to some readers the illustration alludes to ironic photographic references to the American steelworkers atop the skyscrapers of the 30 's and 40's. The examples above may show how texts can 'construct implied readers who are more actively involved in the production of meanings' (McCallum 1996, p.408) but also display the humour that may be derived from linguistic and visual play as dependent on both the textual and intertextual experience of the audience.

Riddle's handling of metaphoric idioms to create humour is based on semiotic playfulness and exploitation of the dual interacting codes. The illustration of the elephant spurting water is accompanied by the words. 'But the elephant blew it when he could no longer resist the fountain in the town'. Here the verbal text juxtaposes figurative and literal interpretations for what the sentence might suggest. Once again, the joke demands the recognition of a textual link, this time to make an equation between the main and the subordinate clause, and again, knowledge of the nature and habits of animals completes the sense of the joke. Without the interaction of the visual code, the pun might represent too complex a cognitive process for young readers. But, as Stephens has noted, 
'the picture book mode may be exploited to bridge the gaps in language by presenting visual clues or parallels' (Stephens 1989, p.34) and the illustration here effectively narrows the sense of both the main and subordinate clauses. In this way the visual code humorously and metafictively draws attention to how language may signify in different ways. A related strategy is used in the doublepage with the words. 'Their best chance was to head for the border. By whatever means.' In the first frame the animals are depicted on a log which carries them headfirst over the crest of a waterfall. In the second frame they appear to have accepted a ride in a lorry. Here the composition effects a hiatus in the rhythm of the conventional prose form of the sentence, by verbally representing the sentence as divided, as well as pictorially representing two separate versions of heading for the border. Division of the sentence into two frames creates a heavy end-focus, which draws attention to the modifying phrase with its indefinite relative. 'whatever'. The positioning of this phrase on the right hand page further weights its signification (see Kress and van Leeuwin 1990,1996 ) and provides a sharp contrast and an element of bathos to the visual code's literal encoding of the metaphoric idiom, 'head for the border', on the left hand page. The key to this kind of semiotic playfulness which seems to question the way language structures reality is thus found in picture book composition. Multiple shifts occur, as the author intermittently pins meaning, constructs an internal position for renders in relation to the text, opens up meaning to readers' conjecture and then reassumes control to pin it again quite differently.

The linguistic register of The Great Escape is marked by the use of clichés, such as 'something was brewing', 'hot on their trail', 'fancied his chances', 'picked up jobs'. 'things were finally working out' and so on. Cliché may operate as a means of closing off meaning, because of the assumptions generally attached to such phrases. In The Great Escape, however, the narrative's disjunctive structure tends to foreground the superficiality of the clichés, thereby suggesting that meaning lies at a deeper textual level.

With apparent simplicity, The Great Escape encodes its search for meaning through play by utilising a familiar children's story schema, that of escape, freedom/ adventure, and recapture or return home. In the story the four animals' freedom is assured only as long as they can disguise their true identity. Riddle uses the schema to address ontological questions, such as the truth status of the narrative and the 'blending in' of the escaped animals to the 'real' world outside. In its thematic choice The Great Escape echoes a prevalent concern of metafictional novelists, that of role-playing and fictionality as themes. This 'minimal form of metafiction' may 'present characters who are involved in a duplicitous situation requiring the perpetration of some form of pretence or disguise' (Waugh 1984, p.116). Stephens, too, has described how roles and role-playing in the context of children's fiction contribute to the metafictive reading of a text and has demonstrated ways in which disguise, 'the taking on of a different, temporary role or identity which is put off again at the end of the episode', can function interrogatively (1992a a p. 133). In this vein I will extend my comparison between cartoons as cultural commentary and metafictional picture books. Both genres tend to utilise their ironic form to tackle questions of contemporary identity. In The Great Escape the explicit challenge to the child audience relates to their textual subjectivity, but, like the characters with whom they are ultimately invited to identify, children's social fit 'on the outside' is perceived as problematic, because they cannot help being what they really are. One by one, the characters are returned to City Zoo, although their status as story heroes is maintained even in recapture. The exception is the flamingo whose 'time out' is not redeemed and his transgression is permanent at the level of embedded story. When he reappears in the last story illustration, where the animals regroup as if in a photograph, story closure is exposed as a fictional device. Morally, then, while the text encodes the possibility of escaping the net of authority, overriding this departure from the norm is the moral sense that victory lies in the fun of adventure, and by extension, in the enjoyment and mastery of the fictional game.

\section{NOTES}

1. As Nelson has pointed out, incongruity theories date from the nineteenth century.

2. Kress and van Leeuwin (1996) have discussed the 
composite text as 'multi-modal', referring to the 'text whose meanings are realised through more than one semiotic code' (p. 183)

3. The term mise en abyme refers to a mirroring device within the narrative, which is used to refiect the fictional word itself. See McCallum ( 1996 ) for a short discussion of its application in children's texts.

\section{REFERENCES}

Grieve, Ann (1993) 'Postmodernism in picture books', Papers 4, 3, 15-21.

Grieve, Ann (1998) 'Metafictional play in children's fiction', Papers 8, 3, 5-15.

Hunt, Peter (1988) 'What do we lose when we lose allusion?' Signal 57, 212-22.

Hutcheon, Linda (1984) Narcissistic Narrative - The Metafictional Paradox. New York and London, Methuen.

Kress, Gunther and van Leeuwin, Theo $(1990,1996)$ Reading Images. London and New York, Routledge

Langer, Susanne (1953) Feeling and Form. London, Routledge and Kegan Paul.

Lewis, David (1990) 'The constructedness of texts: picture books and the metafictive', Signal 62, 131 - 46.

Lodge, David (1981) Working with Structuralism. Boston, Routledge and Kegan Paul.

McCallum, Robyn (1996) 'Metafiction and experimental fiction' in Peter Hunt (ed) International Companion Encyclopedia of Children's Literature. New York and London, Routledge.

Mackey, Margaret (1990) 'Metafiction for beginners: Allan Ahlberg's Ten in a Bed', Children's Literature in Education 21, 3, 179-87.

Marzolf, Donald P. and Deloache, Judy S. (1997) 'Search tasks as measures of cognitive development' in Foreman and Gillett (eds) Handbook of Spatial Research Paradigms and Methodologies. East Sussex. Psychology Press.
Moss, Geoff (1992) 'Metafiction, illustration and the poetics of children's literature', in Peter Hunt (ed) Literature for Children: Contemporary Criticism. London, Routledge.

Nelson, T. G. A. (1990) Comedy: An Introduction to Comedy in Literature, Drama and Cinema. Oxford and New York, Oxford University Press.

Nodelman, Perry (1988) Words About Pictures. The Narrative Art ofChildren's Books. Athens and London, The University of Georgia Press.

Ommundsen, Wenche (1993) Metafictions? Reflexivity in Contemporary Texts. Carlton, Melbourne University Press.

Pagnol. Marcel (1947) Notes sur le rire. Paris, Nagel.

Riddle, Tohby (1997) The Great Escape from City Zoo. Sydney, Auckland, London, Harper Collins.

Stephens, John (1989) 'Language, discourse and picture books, Children's Literature Association Quarterly $\$ 4,3,106-110$.

Stephens, John (1992a) Language and Ideology in Children 's Fiction. Lundon and NewYork, Longman.

Stephens, John (1992b) 'Modernism to postmodernism. or The line from Insk to Onsk: William Mayne's Tiger's Railway', Papers 3, 2. 51-59.

Stephens, John and Waterhouse, Ruth (1990) Literature, Language and Change. London and New York, Routledge.

Waugh, Patricia (1984) Metafiction - The Theory and Practice of Self-Conscious Fiction. London and New York, Routledge.

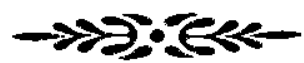

\section{BIOGRAPHICAL NOTE}

Cheryl McMillan completed her Master of Arts at Macquarie University on the use of fantasy and realism in the work of Chris van Allsburg. She is currently doing her Ph.D on postmodernity in children's literature at Macquarie. 